\title{
JUURNAL.RU
}

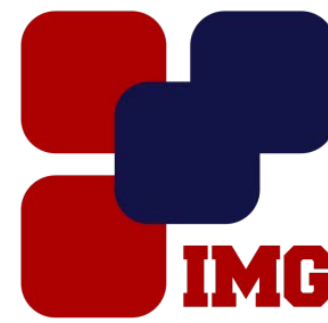
IVANOY Management GROUP

Иванов В.В. Научно-исследовательский институт прикладной экологии Севера Северо-Восточного федерального университета им. М.К. Аммосова Якутск, Россия

doi: 10.18411/lj-30-11-2016-2-06

idsp 000001:lj-30-11-2016-2-06

\section{Основные геоэкологические факторы воздействия угледобычи на экосистемы Южной Якутии}

\begin{abstract}
Аннотация
В статье рассмотрены результаты исследований состояния природной среды в зоне воздействия горных работ на разрезе «Нерюнгринский», отрабатывающего одноименное месторождение угля в условиях Южной Якутии. Исследованиями выявлено значительное распространение продуктов выбросов в атмосферный воздух, которое негативно влияет на геохимический состав почвы, что отражается на жизнеспособность растительного покрова близлежащей к разрезу территории.

Ключевые слова: Экосистемы, угледобыча, природная среда, зона воздействия, почвенно-растительный покров, микроэлементный состав.

В настоящее время по запасам угля Республика Саха (Якутия) занимает первое место в Дальневосточном округе $(47 \%$ запасов кат $\mathrm{A}+\mathrm{B}+\mathrm{C} 1$ Дальневосточного округа)[1]. На территории Якутии расположены основная часть Ленского угольного бассейна, Южно-Якутский бассейн с высококачественными коксующими углями, Зырянский бассейн, восточная часть Тунгусского бассейна (месторождение Черное), отдельные разрозненные месторождения северо-восточной части Якутии (Уяндинское, Куларское) и месторождение бухты Тикси (Согинское) [2].

Из-за наиболее выгодных условий расположения, сравнительно развитой транспортной схемы в последние десятилетия много внимания уделяется освоению Южно-Якутского угольного бассейна, балансовые запасы которого приведены в Таблице 1.
\end{abstract}


Таблийа 1.

Запасы и ресурсы углей Южно-Якутского бассейна [3]

\begin{tabular}{|c|c|c|c|}
\hline Угленосные районы & $\begin{array}{c}\text { Всего геологических } \\
\text { запасов, млн. т. }\end{array}$ & $\begin{array}{c}\text { Балансовые запасы } \\
\left(\mathrm{B}+\mathrm{C}_{1}+\mathrm{C}_{2}\right)\end{array}$ & $\begin{array}{c}\text { Прогнозные ресурсы } \\
\left(\mathrm{P}_{1}+\mathrm{P}_{2}+\mathrm{P}_{3}\right)\end{array}$ \\
\hline Усмунский & 4320 & 470 & 3850 \\
\hline Алдано-Чульманский & 25290 & 6490 & 18800 \\
\hline Гонамский & 3360 & - & 3360 \\
\hline Токинский & 24540 & 2800 & 21740 \\
\hline Всего по бассейну & 57510 & 9660 & 190 \\
\hline В том числе: & & & 25490 \\
\hline Для открытой отработки & 3320 & 3130 & 22070 \\
\hline $\begin{array}{c}\text { Для штольневой } \\
\text { отработки }\end{array}$ & 28720 & 3230 & \\
\hline Для шахтной отработки & 25470 & 3400 & \\
\hline
\end{tabular}

В этом регионе Якутии с 1976 года и по настоящее время основным объектом угледобычи является разрез «Нерюнгринский», эксплуатирующий одноименное месторождение коксующего угля.Объемы добычи на разрезе за 1013 и 2014 гг. составляли соответственно 9181 и 8969 тыс. т.

На базе уникальных угольных месторождений здесь сложился промышленный комплекс с развитой инфраструктурой, транспортной схемой, вырос значительный для условий Севера город Нерюнгри.

В настоящее время ведутся работы по созданию других крупных угледобывающих объектов на месторождениях Эльгинское и Чульмаканское.

В биогидроклиматическом и мерзлотном отношении ландшафтыЮжной Якутиивесьма неоднородны и изменяются от горных редколесий до горнотаежных лесов.Распространение мерзлоты прерывистое и островное.

Температура многолетнемерзлых пород для горных редколесий с прерывистыми многолетнемерзлыми породами (ММП) изменяется в пределах от $0 о \mathrm{C}$ до - 4оС в мерзлых, и до 2оС в талых горных породах. Сезонно-талый слой колеблется в пределах 1 - 5 м.

В горно-таежных лесах по сравнению с горными редколесьями более благоприятные природно-климатические условия, которые способствуют повышению бонитета до II - III, сомкнутости крон - 0,5 - 0,7 и обилию травянокустарничковых видов. Здесь распространены наряду с лиственичниками леса с участием сосны, кедра, ели сибирской, местами ели аянской.

Температура пород в области прерывистых ММП изменяется от 0оС до $3,50 \mathrm{C}$ в мерзлых и до 2оС в талых горных породах. На участках островной мерзлоты температура пород составляет от 0оС до -2оС. Мощность сезонноталого слоя от 1 до 4 м в прерывистых ММП и от 1 до 4,5 м в области островных ММП [4].

Открытая разработка угольных месторождений сопряжена, как и вся деятельность по добыче полезных ископаемых, с негативным воздействием на природные комплексы.

Особо заметные изменения с полным выводом из экологического равновесия почвенно-растительного покрова наблюдаются в зоне прямого воздействия горных работ в пределах земель, отведенных под поле разреза. По 
состоянию на 01.01.2015 г. разрезом «Нерюнгринский» для проведения горных выработок, размещения отвалов вскрышных пород, промплощадок, автодорог и инженерно-технических сетей нарушено около 3,4 тыс. га земель[1].

Для оценки общего влияния на экосистемы близлежащих территорий разработки данного угольного разреза нами с 2003 г. проводились комплексные экологические исследования по схеме элементный состав продуктов рассеивания (вскрышные породы, уголь) - химический и микроэлементный состав снежного покрова - химический и микроэлементный состав и общее экологическое состояние почвенно-растительного покрова. Результаты данных эколого-оценочных работ позволили установить следующее.

Основными источниками пылеобразования на разрезе являются буро взрывные, выемочно-погрузочные, разгрузочные, транспортные работы, а также ветровая эрозия - сдувание пыли с обнаженных площадей отвалов, с угольных и породных уступов, с поверхности угольных складов.

В табл. 2 приведены средние объемы выбросов разреза по данным Нерюнгринской инспекции охраны природы.

Таблий 2.

Выбросы загрязняющих веществ в атмосферу разреза «Нерюнгринский»

\begin{tabular}{|c|c|c|}
\hline Наименование вещества & Код вещества & Фактический выброс, т/год \\
\hline Оксид железа & 123 & 0,0737 \\
Марганец и его соединения & 143 & 0,0139 \\
Свинец и его соединения & 184 & 0,0002 \\
Хром шестивалентный & 203 & 0,0021 \\
Диоксид азота & 301 & 113,6224 \\
Кислота серная & 322 & 0,0025 \\
Сажа & 328 & 0,0256 \\
Диоксид серы & 330 & 0,1678 \\
Оксид углерода & 337 & $334,8536 *$ \\
Фториды газообразные & 342 & 0,0139 \\
Фториды плохорастворимые & 344 & 0,0091 \\
Бензол & 602 & 0,0044 \\
Ксилол & 616 & 0,0045 \\
Толуол & 621 & 0,0074 \\
Масла аэрозоль & 2735 & 0,012 \\
Взвешенные вещества & 2902 & 2079,2266 \\
\hline
\end{tabular}

Анализы пылевой и геохимической составляющей снежного покрова показывают сложную картину распределения техногенной нагрузки вокруг угольного разреза. Шлейф загрязнения атмосферными выбросами занимает значительную площадь в 550 - 750 км2 и тянется в юго-восточном направлении от карьера. Данная картина подтверждается и космосьемками поверхности снежного покрова. Необходимо отметить, что при этом в суммарное загрязнение накладываются атмосферные выбросы г. Нерюнгри, Нерюнгринской ГРЭС, Амуро-Якутской автомагистрали, железной дороги.

Анализ данных контролирующих органов показывает, что основную массу выбросов в атмосферу разреза «Нерюнгринский» занимают взвешенные вещества, оксиды азота, оксид углерода, углеводороды, сажа. В состав пылегазовых смесей входят также такие опасные для окружающей среды 
компоненты как свинец, марганец и их соединения, хром шестивалентный, диоксид серы, оксид железа и другие химические вещества.

По данным исследований микроэлементного состава углей Нерюнгринских месторождений относительно высокое содержание имеют титан, содержание которого в среднем составляет около 1,5 г/кг, марганец около 0,3 г/кг, фосфор -135 мг/кг, цинк - 58 мг/кг, свинец - около 20 мг/кг соответственно. Эти же элементы преобладают и в твердой фазе проб снежного покрова.

Резко выделяется локальное техногенное загрязнение у угольного разреза на юго-восточном направлении в районе совместного воздействия карьера и обогатительной фабрики. Здесь наблюдается максимальное накопление в снежном покрове продуктов атмосферного загрязнения, пылевая нагрузка которых достигает до 150 т/км2. В зону загрязнения попадает часть жилого массива (старый город), промышленный район города, дачные участки.

В данной зоне в жидкой фазе снежных проб наблюдается тенденция увеличения концентраций цинка, свинца, меди, железа и марганца, что характерно для участков, подвергающихся усиленному загрязнению угольной пылью.

Исследования почвенного покрова показали, что на исследуемой территории значительные концентрации микроэлементов отмечаются в моховом покрове, лесной подстилке. В них содержание меди - 53,5 мг/кг, цинка - 152,0 мг/кг, свинца - 63,0 мг/кг, что значительно выше принятых ПДК. В гумусовом горизонте отмечается аномальная концентрация титана - 5833 мг/кг, повышены содержания марганца, молибдена[5].

Биогеохимическими исследованиями выявлено накопление практически во всех видах опробованных растений таких элементов как фосфор, марганец, цинк, молибден.

Усиленное антропогенное воздействие привело к ухудшению экологического и санитарного состояния в лесных сообществах вокруг разреза. Здесь наблюдается значительное (почти на половину) изменение растительности за счет внедрения более устойчивых видов разнотравья и кустарников. Растительность под воздействием Нерюнгринского промышленного комплекса находится в различной степени трансформации, которая в зависимости от розы ветров отмечается до 70 км и более к югу - юго-востоку от разреза.

Полученные данные подтверждаются результатами ухудшение качества среды вокруг разреза, которая выражается в повышении показателей нарушения стабильности развития растений и животных. Наиболее значительные нарушения стабильности индивидуального развития организмов наблюдаются в непосредственной близости от разреза и на пониженных участках рельефа, где происходит накопление загрязнителей [6].

Таким образом, при разработке угольных месторождений основными факторами негативного воздействия на природную среду являются прямое механическое разрушение почвенно-растительного покрова территории, 
геохимическое загрязнение значительных площадей атмосферными выбросами. При этом ухудшение экологического состояния испытывают практически все основные составляющие экосистемы рельеф, атмосфера, почвеннорастительный покров, животный мир. Атмосферное загрязнение во много раз расширяет зону косвенного воздействия разреза.

\section{Литература}

1. Государственный доклад о состоянии и охране окружающей среды Республики Саха (Якутия) в 2014 году. - Якутск: Министерство охраны природы, 2015. - 250 с.

2. Бычев М.И., Яковлев В.Л., Петрова Г.И. Угли Якутии и перспективные направления их использования. - Якутск: ЯНЦ СО РАН, 1996. - 120 с.Производственное объединение «Якутуголь».- Иркутск: Управполиграфиздат, 1986. - 44 с.

3. Поляков Н.П. Состояние, перспектиыв и проблемы развития угольной минерально-сырьевой базы Южной Якутии // Пути эффективного использования экономичекого и промышленного потенциала ЮжноЯкутского региона в XXI веке. Сб. науч. трудов. Т. 2. Якутск: Изд-во Якутского ун-та, 2000. С. 3-11.

4. Мерзлотные ландшафты Якутии (Пояснительная записка к «Мерзлотноландшафтной карте Якутской АССР масштаба 1:2500000) // Федоров А.Н., Ботулу Т.А., Варламов С.П. и др.. - Новосибирск: ГУГК, 1989. - 170 с.

5. Тарабукина В.Г., Иванов В.В., Макаров В.С., Кудинова 3.А. Загрязнение почвенного покрова выбросами объектов промышленного комплекса в условиях Южной Якутии // Проблемы региональной экологии. №2, 2009 г. - C. 24-28

6. Шадрина Е.Г., Вольперт Я.Л., Данилов В.А., Шадрин Д.Я. Биоиндикация воздействия горнодобывающей промышленности на наземные экосистемы Севера: Морфогенетический подход: Наука, 2003. - 110 с. 